\title{
Om betydningen og bruken av de norske modalpartiklene da og a
}

\author{
Thorstein Fretheim
}

\section{Innledning ${ }^{1}$}

Det norske pro-adverbet $d a$ i (1) viser at talehandlingen er en konklusjon som blant annet skyldes innholdet i det man identifiserer som diskursantesedenten til dette anaforiske ordet. $D a$ representerer en sannhetsbetingelse som bidrar til identifisering av den proposisjonen produsenten av (1) kommuniserer.

$$
\text { Da blir du ikke forkjøla. }
$$

Det indeksikalske uttrykket $d a$ i (1) refererer mest sannsynlig til noe produsenten presenterer som et tiltak for å unngå forkjølelse. Mindre sannsynlig av pragmatiske grunner er tanken at det refereres til et framtidig tidspunkt, men $d a$ fungerer både som kondisjonal og som temporal anafor, og kondisjonalfunksjonen kan forsterkes til en kausalfunksjon i passende diskurssammenhenger.

Den etterstilte, ubetonte utgaven av $d a$ i (2) er derimot en modalpartikkel som ikke uttrykker noen sannhetsbetingelse, men sier noe om produsentens epistemiske holdning («epistemic stance») overfor den uttrykte proposisjonen, heretter ofte benevnt den uttrykte tanken eller antagelsen (Fretheim 2014, 2015a; Fretheim, Boateng \& Vaskó 2002; van Dommelen, Fretheim \& Nilsen 1998; Borthen 2014).

$$
\text { Du blir ikke forkjøla, da./? }
$$

«./?» markerer her at setningen er pragmatisk tvetydig, den kan brukes for å påstå at adressaten ikke kommer til å bli forkjøla, eller for å be adressaten bekrefte at det ikke kommer til å skje. Hvis produsentens intensjon er å påstå at innholdet i ytringen er sant, er talehandlingen av den korrigerende sorten. Adressaten må først må ha sagt noe som impliserer det motsatte av hva den negative polariteten i setningen gir beskjed om.

Det finnes også en tredje bruk av partikkelen $d a$ i (2). Den kjennetegnes ved at produsenten stiller seg tvilende til det kognitive innholdet $\mathrm{i}$ ytringen, og vil vite om adressaten virkelig tror på det. Denne bruksmåten gjør det

1 Takk til redaktøren Peter Ström, til to anonyme fagfeller, til Wim van Dommelen og ikke minst en varm takk til Gunilla Byrman for godt vennskap gjennom førti år. Min takk går også til to ruvende skikkelser innenfor utforskingen av svensk intonasjon og ordprosodi som ikke lenger er med oss: Eva Gårding og Gösta Bruce. 
mulig for en stor del av den østnorske befolkning å fritt erstatte $d a$ med den utpreget muntlige partikkelen $a$. Forholdet mellom semantikken til partiklene $d a$ og $a$ og de pragmatiske konsekvensene av valget mellom dem vil bli drøftet utførlig i denne artikkelen.

Mens anaforen $d a$ i (1) representerer én enkelt proposisjon som må være sann for at konklusjonen blir sann, står partikkelen $d a$ i (2) for den lille mengden av uspesifiserte tanker som utgjør den konteksten adressaten må trekke veksler på for å forstå hva produsenten har til hensikt å formidle. ${ }^{2}$

Det frontstilte, anaforiske adverbet $d a$ i (1) har vært utsatt for grammatikalisering. Som så ofte ellers når språklige uttrykk grammatikaliseres, går det sannhetsfunksjonelle semantiske elementet i uttrykket tapt, men hva slags semantiske trekk ved det anaforiske opphavet kan tenkes å være bevart i den grammatikaliserte partikkelen $d a$ ? Konklusjonen i (1) forutsetter at tanken om at adressaten kan bli forkjøla, må være et diskurstema på det punktet i samtalen der (1) forekommer. Adressaten behøver ikke å erklære seg enig i konklusjonen til produsenten, men produsenten formoder nok at adressaten ikke vil forkaste den uten videre. I henhold til relevansteoriens terminologi betyr dette at det kognitive innholdet i (1) antas å være GJENSIDIG MANIFEST, i det aktuelle tilfellet manifest i sterk grad for produsenten, men antatt manifest også for adressaten som skal vurdere om konklusjonen holder, gitt at man godtar den betingelsen som $d a$ setter.

For Sperber \& Wilson (1986/1995) er en tanke manifest for et individ på et gitt tidspunkt i den grad hen er i stand til å representere den mentalt og å bedømme den som sann (eller muligens sann, for manifesthet i Sperber \& Wilsons forstand er et graderbart fenomen). I dette perspektivet vil kommunikasjon essensielt gå ut på at språkbrukere i verbal interaksjon med andre tilstreber tilstander av konsensus, det vil si gjensidig manifesthet forbundet med tanker om hvordan verden er beskaffen. Dette kan skje ved at produsenten av en ytring formår å gjøre en tanke manifest for adressaten eller å øke graden av manifesthet i adressatens sinn fra relativt lav til høy. Det kan også skje ved at produsenten klarer å svekke den graden av manifesthet som en bestemt tanke har for adressaten og i ytterste konsekvens får tanken eliminert fra adressatens kognitive omgivelser (Sperber \& Wilsons «cognitive environment»), det vil si den totale mengden

\footnotetext{
2 Min oppfatning av hvordan begrepet kontekst bør forstås, bygger på følgende relevansteoretiske definisjon av begrepet: «A context is a psychological construct, a subset of the hearer's assumptions about the world. It is these assumptions, of course, rather than the actual state of the world, that affect the interpretation of an utterance. A context in this sense is not limited to information about the immediate physical environment or the immediately preceding utterances: expectations about the future, scientific hypotheses or religious beliefs, anecdotal memories, general cultural assumptions, beliefs about the mental state of the speaker, may all play a role in interpretation.» (Sperber \& Wilson 1986/1995: 15-16).
} 
av forestillinger om verden som er manifeste for et individ på et gitt tidspunkt.

Sperber \& Wilson fant det nødvendig å introdusere begrepet gjensidig manifesthet («mutual manifestness») som et alternativ til det kjente begrepet «gjensidig viten» («mutual knowledge», Clark \& Marshall 1981). A tolke eller «lese» den andre partens tanker er et sine qua non i mellommenneskelig kommunikasjon, men å hevde at noe er gjensidig kjent for produsent og adressat, er i følge Sperber \& Wilson å godta en kode-modell for produksjon og forståelse av språklige stimuli istedenfor en modell som tar hensyn til at kommunikasjon muliggjøres av samspillet mellom grammatikkbestemt koding (og avkoding) og vår evne til å trekke relevansdrevne slutninger. Sperber \& Wilson sier:

By the very definition of mutual knowledge, people who share mutual knowledge know that they do. If you do not know that you have mutual knowledge (of some fact, with someone), then you do not have it. Mutual knowledge must be certain, or else it does not exist; and since it can never be certain it can never exist.

(Sperber \& Wilson 1986/1995: 19-20, forfatternes kursivering)

I pakt med sin relevansteori ${ }^{3}$ fremmer Sperber $\&$ Wilson hva de anser for å være et mer edruelig grunnsyn, nemlig at kommunikasjon alltid er «risky business» fordi det bygger på slutninger om produsentens intensjon som kan synes rimelige, men som det normalt vil hefte en usikkerhet ved av den enkle grunn at slutninger om andres tanker er langt fra ufeilbarlige. Den konvensjonelle grammatikkbestemte betydningen som uttrykkes ved hjelp av en språklig stimulus, gir ikke adressaten noen mulighet for å avkode det kommuniserte innholdet direkte. Det semantikken til en setning tilbyr adressaten, er kun et nødvendig utgangspunkt for å foreta rette valg $\mathrm{i}$ gjennomføringen av den pragmatiske, altså slutningsbaserte tolkningen av en bestemt ytring av setningen innenfor rammen av en premissgivende kontekst. Valget av slutninger om hva produsenten mener med sin ytring, blir bestemt av setningens kontekstfrie semantiske struktur i kombinasjon med den konteksten som adressaten trekker veksler på, men man har ingen garanti for at de slutningene som trekkes i den pragmatiske fasen av det som trengs for å forstå innholdet, samsvarer med hva produsenten har til hensikt

\footnotetext{
3 For relevansteoretikerne er relevans en egenskap ved stimuli, ikke-verbale så vel som verbale, men som lingvist er man opplagt nok mest opptatt av språklige stimuli, ytringer. En ytring er relevant for oss i den grad den gir oss en viss kognitiv effekt som resultat av at den informasjonen vi utleder fra det iboende innholdet i ytringen, samspiller med informasjon som allerede er lagret i vårt minne. Kognitive effekter består i at de (i) befester antagelser vi hadde fra før, (ii) motsier og dermed eliminerer tidligere antagelser, og viktigst (iii) fører til nye slutninger og dermed ny kunnskap gjennom å bli integrert i en delmengde av våre eksisterende antagelser om verden. Jo større de kognitive effektene av mental prosessering av en ytring, jo mer relevant er ytringen, og jo mer mental innsats som kreves for at et individ skal kunne oppnå slike effekter, jo mindre relevant er ytringen. Optimal relevans foreligger når det er god balanse mellom oppnådde kognitive effekter og mentale kostnader forbundet med å oppnå dem.
} 
å kommunisere. At produsenten oppfatter en gitt tanke som gjensidig manifest, innebærer at det legges til grunn at begge parter kan se for seg at den uttrykte proposisjonen er sann, eller kan være sann - en mye mer beskjeden antagelse enn at begge parter vet hva den andre anser for å være sant. Jeg vil argumentere for at et grunnleggende semantisk trekk ved modalpartikkelen $d a$ som er nedarvet fra anaforen, er nettopp dette at innholdet $i$ ytringen presenteres som antatt gjensidig manifest. ${ }^{4}$

Det er ingen grunn til å betvile at et av de viktigste språklige fenomenene som samspiller med modalpartikkelen, er det intonasjonsmønsteret som produsenten legger oppå den syntaktiske formen, i særdeleshet den bestemte inndelingen i prosodiske konstituenter som gir beskjed om den hierarkisk oppbygde intonasjonsstrukturen til ytringen (se følgende avsnitt), heretter omtalt som produsentens intonasjonsfrasering. Denne viser noe vesentlig om hvordan partikkelen $d a$ skal behandles av adressaten i den pragmatiske tolkingsprosessen. Intonasjonsfraseringen bidrar til å kontekstualisere ytringen og dermed sikre at den blir relevant for adressaten. Samspillet mellom ikke-verbale kontekstuelle premisser, intonasjonsmønsteret til produsenten og semantikken til partikkelen $d a$ gjør at innholdet av en talt ytring av (2) noen ganger vil bli oppfattet som sterkt manifest for produsenten og antatt svakere manifest for adressaten (påstander), andre ganger som antatt sterkt manifest for adressaten, men svakere manifest for produsenten (ledende spørsmål om bekreftelse).

Partikkelen $d a$ koder ikke et begrepsinnhold, det har i stedet en prosedural semantikk («procedural semantics»). At et språklig uttrykk har en prosedural semantikk (for litteratur om dette, se Blakemore 1987, 2002; Wilson 2011, 2016; Wilson \& Sperber 1993; Escandell-Vidal \& al 2011; Hall 2007; Ahern \& Leonetti 2004; Fretheim 2000, 2011, 2014, 2015a, 2015b, 2017a, 2017b, 2018, 2019), betyr at uttrykket instruerer adressaten om hvordan det bør trekkes kontekstdrevne slutninger for å oppnå en tolkning av ytringen som gir optimal relevans, altså mest mulig kognitiv effekt for minst mulig prosesseringskostnad (Sperber \& Wilson 1986/1995; se min fotnote 3 ).

For en stor del av Norges befolkning gjelder det at også modalpartikkelen $d a$ har gjennomgått en grammatikaliseringsprosess. Formelt sett har dette resultert $\mathrm{i}$ et systematisk bortfall av framlydskonsonanten. Partikkelen $d a$ reduseres til ett segment, vokalen $a$, gjennom en grammatikaliseringsprosess som gjerne omtales som sekundær (Givón 1991; Breban 2014) i og med at utgangspunktet for den diakrone prosessen i sin tur er et resultat av grammatikalisering. Mine tanker om hva denne

4 Men som jeg skal vise, er det ikke nødvendigvis slik at produsenten av en ytring som er modifisert av partikkelen da, framstiller innholdet som gjensidig manifest ut fra produsentens egen tolkning av tilgjengelig evidens. Produsenten kan innta samtalepartnerens ståsted og framstille innholdet som gjensidig manifest ut fra den personens perspektiv. I så fall kan utfallet bli at produsenten synliggjør en konflikt mellom eget syn og adressatens syn på verden. Mer om dette utover i artikkelen. 
sekundære grammatikaliseringen har ført til på det semantiske planet, får en sentral plass i resten av denne artikkelen. Det vil framgå at tapet av konsonanten ikke har noe med slurvete uttale å gjøre. Endringen er av systematisk art, og den har ført til utvikling av en ny modalpartikkel i norsk talemål, funksjonelt beslektet med $d a$, men med et mer restriktivt bruksområde.

\section{Den leksikalske betydningen til partiklene da og a samspiller med produsentens intonasjonsfrasering}

\section{Semantikken til $d a$}

Mitt forslag til prosedural leksikalsk semantikk for partikkelen $d a$ er som følger:

Test for relevans antagelsen om at den tanken som ytringen uttrykker, er gjensidig manifest. ${ }^{5}$

Anta at $d a$ representerer en begrenset mengde av proposisjoner som samtalen har gjort tilgjengelig, og som støtter enten den uttrykte tanken eller den kontrære motsatsen.

Muligheten for at $d a$ forbindes med en tanke som direkte motsier den uttrykte tanken («den kontrære motsatsen»), skyldes den spesielle bruken av $d a$ som sammenfaller med bruken av $a$. Jeg vil understreke så sterkt jeg kan, at det ikke er partikkelen alene som formidler den prosedurale informasjonen man forbinder med ytringer som inneholder den. Adressatens oppgave blir å sammenholde den prosedurale semantikken til partikkelen $d a$ med ko-eksisterende fenomen med prosedural betydning, hvorav setningstypen (deklarativ, interrogativ eller imperativ), produsentens intonasjonsmønster og semantikken til eventuelle andre modalpartikler i ytringen er blant de vesentligste. Det spiller dessuten en rolle om partikkelen er en trykklett appendiks til en vertskapssetning, eller om den er plassert $i$ setningens midtfelt, umiddelbart etter det finitte verbet $i$ en hovedsetning, umiddelbart foran det $\mathrm{i}$ en leddsetning. Den setningsinterne plasseringen av $d a$ får lite oppmerksomhet $\mathrm{i}$ denne artikkelen. Jeg er primært interessert $\mathrm{i}$ forholdet mellom de to partiklene $d a$ og $a$, og $a$ finnes utelukkende som ytringsfinal appendiks til en vertskapssetning (se Berthelin 2014; Fretheim 2010, 2014, for synspunkter på $d a \mathrm{i}$ setningsintern posisjon).

5 I Fretheim (2015: 259) fikk den prosedurale semantikken til partikkelen da denne engelskspråklige formen: «Test for relevance the assumption that the expressed proposition $p$ is mutually manifest.» 


\section{Semantikken til $a$}

For partikkelen $a$ gjelder i tillegg til (3) den begrensningen jeg formulerer i (4). Denne instruksen er ikke kodet som en del av den leksikalske semantikken til $d a$, men som antydet ovenfor kan det foreligge kontekstuelle forhold som gjør at en gitt forekomst av $d a$ blir behandlet pragmatisk på samme måte som $a$.

Anta at det foreligger et misforhold mellom den tanken som setningen uttrykker, og de kontekstuelle forutsetningene som partikkelen representerer.

Siden det her pekes på en motsetning mellom den tanken som vertskapssetningen uttrykker, og det produsenten er villig til å underskrive på, får den testen som inngår i semantikken til $d a \mathrm{i}$ (3) et negativt utfall når partikkelen er $a$. Intensjonen om å representere en tilstand av gjensidig manifesthet vil da ikke være knyttet til innholdet i setningen, men isteden til den kontrære motsatsen til den proposisjonen som kan utledes fra vertskapssetningen. Dette er det synspunktet som produsenten selv forfekter (om enn ikke nødvendigvis med total overbevisning). Denne motsetningen mellom setningens semantikk og produsentens epistemiske holdning gjelder uten unntak når partikkelen er $a$ og vertskapssetningen er deklarativ. Jeg skal i hovedsak beskjeftige meg med $d a$ og $a$ etter deklarative setninger, hvor de pragmatiske virkningene av forskjellene mellom dem er tydeligst. ${ }^{6}$

Det misforholdet som nevnes i (4), oppstår bare dersom talehandlingen ikke er en påstand. Man må forutsette en motsetning mellom hva setningen uttrykker og hva språkbrukeren selv står for, og dette blir vanskelig hvis språkbrukeren påstår at den uttrykte proposisjonen er sann.

\section{Eksempler på samspillet mellom intonasjon og etterstilt partikkel $\mathbf{d a}$}

Trondheimsmodellen for norsk intonasjon (primært applisert på østnorsk tale) legger vekt på at det finnes hierarkisk konstituentstruktur i intonasjon så vel som i syntaks (Fretheim 1987, 1991, 1992a, 1992b, 2002, 2017c; Fretheim \& van Dommelen 2012; Nilsen 1992). En intonasjonsytring (IY) består av minimum én, maksimum to fokale fraser (FF). En FF består av et ubestemt antall aksentenheter (AE), minimum én. En AE starter med den trykksterke stavelsen i en betont ordform (ordaksent 1 eller 2), og kan bestå utelukkende av den ordformen som innleder den, eller omfatte en rekke ubetonte ordformer etter den betonte.

De to kommunikativt viktigste tonene i en østnorsk IY er den terminale grensetonen som realiseres fonologisk i ytringens siste stavelse, og den fokale frasetonen som er et definerende trekk ved konstituenten FF, og som

6 Den tidligste beskrivelsen av kontrasten mellom partiklene da og a finnes i Fretheim 1989. 
realiseres fonetisk i den siste stavelsen i en FF. ${ }^{7}$ Den terminale grensetonen har to verdier som står i fonologisk opposisjon til hverandre, en lav vs. en høy (L\% vs. H\%) ytringsfinal tone. Ethvert tilfelle av etterstilt partikkel blir uttalt enten med $\mathrm{L} \%$ eller med $\mathrm{H} \%$, og valget beror delvis på hva grammatikken tillater for den enkelte partikkel, og delvis på produsentens intensjon om å gjøre ytringen mest mulig relevant for adressaten. Den fokale frasetonen som avslutter en FF, er en superhøy tone $\left(\mathrm{H}^{-}\right)$i østnorsk intonasjon. Den framhever den konstituenten som er den nærmeste før $\mathrm{H}^{-}$, men den avgrensende funksjonen $\mathrm{i}$ forhold til det som finnes på den andre siden av FF-grensen, er like viktig. Plasseringen(e) av $\mathrm{H}^{-}$i en IY, korrelert med den syntaktiske frasestrukturen i setningen, legger sterke føringer på adressatens pragmatiske prosessering.

Det prosodiske fenomenet polaritetsfokus er av vesentlig informasjonsstruktuell interesse (Fretheim \& Nilsen 1992). En ytring med uttrykt polaritetsfokus signaliserer at den nye informasjonen i ytringen er begrenset til en tro på at den proposisjonen som vertskapssetningen uttrykker, er sann. Dette kan være en kommunisert tro eller en tro som ikke er produsentens egen, men som metarepresenterer en antatt positiv holdning til den uttrykte proposisjonen som produsenten tillegger en annen, mest typisk adressaten. ${ }^{8}$ Hakeparentesene i de dataene jeg kommenterer i dette og senere avsnitt, gjengir den hierarkiske strukturen i en IY. Merkelappene AE, FF og IY er plassert i høyre kant av den gjeldende konstituenten. ${ }^{1}$ og ${ }^{2}$ står for ordaksent, ofte kalt «akut» vs «grav» i svensk litteratur. Dataene i (5)-(8) er hentet fra Oslo-delen av talemålskorpuset NoTA fra Tekstlaboratoriet, Universitetet i Oslo. Det finnes ingen markering av intonasjonsstruktur i korpuset, så det er jeg selv ansvarlig for.

I (5) er selvfølgelig modal appendiks sammen med $d a$.

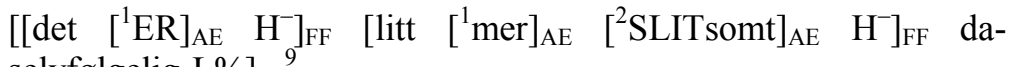

$$
\begin{aligned}
& \text { selvfølgelig-L\% }]_{\mathrm{IY}}{ }^{9} \\
& \text { (28 år gammel mann fra Majorstua, Oslo) }
\end{aligned}
$$

Liksom da presenterer også selvfølgelig innholdet i den modifiserte setningen som gjensidig manifest, men mens partikkelen $d a$ alene kunne ha representert et knippe kontekstuelle premisser som produsenten tillegger

\footnotetext{
7 Stigninger og fall i grunntoneverdi betrakter jeg som automatiske fonetiske overganger mellom fonologisk distinktive, statiske toner som realiseres i bestemte stavelser i den hierarkiske IY-strukturen.

8 En metarepresentasjon er en representasjon av en representasjon, f.eks. en skriftlig gjengivelse av en talt ytring eller et sitat fra en bok eller en samtale (Noh 2000; Sperber 2000).

9 I (5) er ordformene det, litt og sekvensen da selvfølgelig ekstrametriske elementer i IY'en, i den forstand at de ikke tilhører noen AE (Fretheim 2017c). De domineres direkte av en høyere kategori i det prosodiske hierarkiet, FF for det og litt, IY for da selvfølgelig.
} 
adressaten, vil selvfølgelig alltid måtte forbindes med produsentens egne kontekstbestemte forutsetninger for at ytringen framstår som relevant.

I (6) opptrer de angitte fokale frasetonene innenfor et argument til et transitivt verb. (6) er en del av et opptak av fortellingen til en 27 år gammel kvinne fra Vestre Aker (en bydel i Oslo). Hun snakker om hva hun setter så stor pris på i sommersesongen. De to transkriberte IY'ene avsluttes med $d a$. I tillegg finnes det to tilfeller av aksentuert anaforisk adverb $d a$, med temporalt innhold i annen linje og kausalt innhold i fjerde linje. Utrolig fungerer her som gradsadverb, og norske gradsadverb som veldig, svaert, usedvanlig, og altså utrolig, er like gode polaritetsfokusmarkører som en finitt verbform. I den siste av de transkriberte ytringene er det infinitiven $g \stackrel{a}{ }$ som realiserer polaritetsfokus ved hjelp av frasetonen $\mathrm{H}^{-}$.

$$
\begin{aligned}
& {\left[[ j a \text { jeg } [ { } ^ { 1 } \text { syns-det-er-u } ] _ { \mathrm { AE } } [ { } ^ { 1 } \mathrm { TROlig } ] _ { \mathrm { AE } } \mathrm { H } ^ { - } ] _ { \mathrm { FF } } \left[\left[{ }^{2} \text { morsomt-med }\right]_{\mathrm{AE}}\right.\right.} \\
& \left.\left.\left[{ }^{2} \mathrm{BLOMster}\right]_{\mathrm{AE}} \mathrm{H}^{-}\right]_{\mathrm{FF}} \text { da-L\% }\right]_{\mathrm{IY}} \\
& \text { og da er jo det å gå i skogen om sånn i juni og sånn utrolig fint. } \\
& \text { Men holdt på å si de siste årene så var jeg så utrolig allergisk, } \\
& \text { så da tenkte jeg at det kanskje var litt dumt, } \\
& {\left[\left[\text { men }\left[{ }^{1} \text { nå }\right]_{\mathrm{AE}} \text { har jeg liksom .. ja .. be }\left[{ }^{1} \text { gynt-å }\right]_{\mathrm{AE}}\left[{ }^{1} \mathrm{G} \AA-\mathrm{i}\right]_{\mathrm{AE}} \mathrm{H}^{-}\right]_{\mathrm{FF}}\right.} \\
& {\left[\left[{ }^{1} \text { skogen-om }\right]_{\mathrm{AE}}\right.} \\
& \left.\left.\left[{ }^{2} \text { SOMMeren-igjen }\right]_{\mathrm{AE}} \mathrm{H}^{-}\right]_{\mathrm{FF}} \text { da-L\% } \%\right]_{\mathrm{IY}}
\end{aligned}
$$

Både blomstene $\mathrm{i}$ den første ytringen og sommeren $\mathrm{i}$ den siste er diskursgitte, tematiske begreper på det punktet i diskursen hvor (6) ble produsert. I begge disse ytringene impliserer bruken av polaritetsfokus i første FF at innholdet i neste FF skal betraktes som gitt i samtalen. Kvinnen hadde allerede nevnt sin begeistring for blomster. Innledningen men nå i den siste ytringen forbereder adressaten på et utsagn som står i kontrast til den tidligere tanken om at det kan være fysisk utfordrende for en allergiker å tilbringe tid i skogen. At innholdet i ytringen skal betraktes som gjensidig manifest, understrekes av intonasjonsfraseringen i samspill med den finale partikkelen $d a$. Det blir brukt en perfektumskonstruksjon med et infinitivskomplement, og innenfor dette komplementet til verbalet har ... begynt har produsenten to verbformer å velge mellom for å markere polaritetsfokus: partisippformen begynt eller infinitiven $g a ̊$.

Det finnes ikke et eneste treff på partikkelen $a$ etter en deklarativ vertskapssetning i NoTa-materialet. Derimot har jeg funnet eksempler på bruk av etterhengt $d a$ der $a$ ville ha vært et mulig valg, et fullgodt alternativ som ikke endrer innholdet på noen måte, men som kanskje kunne redusere prosesseringstiden for adressaten. (7) er et typisk tilfelle, og et interessant tilfelle, for her skal ikke den negative polariteten forbindes med hva som er sant eller usant (epistemisk modalitet). Snarere reflekterer den negative polariteten i (7) produsentens forsøk på å påvirke adressaten til å overveie å 
få med seg den konserten det refereres til, det motsatte av hva negasjonen i vertskapssetningen uttrykker. ${ }^{10}$

$$
\begin{aligned}
& {\left[\left[\mathrm{du}\left[{ }^{1} \mathrm{SKA}{ }^{\prime}-{ }^{\prime} k \text { ke-på }\right]_{\mathrm{AE}} \mathrm{H}^{-}\right]_{\mathrm{FF}}\left[{ }^{2} \mathrm{KONsert-i-morra}\right]_{\mathrm{AE}} \mathrm{H}^{-}\right]_{\mathrm{FF}} \text { da-L\% }{ }_{\mathrm{IY}}} \\
& \text { (26 år gammel mann fra småbyen Svelvik ved Drammensfjorden, } \\
& \text { bosatt i Oslo) }
\end{aligned}
$$

Den negative polariteten står i kontrast til produsentens egen preferanse. I henhold til definisjonen i (3) er det den kontrære motsatsen til den uttrykte tanken som formidles i (7). Mannen har tydeligvis positive forventninger til det som kommer til å skje på scenen, og oppfordrer på indirekte vis adressaten til å skaffe seg billett. Adressaten har ikke sagt eller gjort noe som kan tyde på at han har til hensikt å gå på konserten, så produsenten syns han trenger å bli minnet på den. Den konsonantløse partikkelen $a$ kunne ikke erstatte $d a$ i (5) eller (6), men i (7) ville motsetningen mellom den negative proposisjonen og produsentens egne tanker om saksforholdet ha tillatt bruk av $a$ som alternativ til $d a$.

(7) viste en negativ setning med trykklett negasjonsoperator 'kke, men i nektende setninger er det ofte ordet ikke som utheves for å markere polaritetsfokus, som i (8) fra NoTa. Hudiksvall som reisemål er et lokalt samtaletema, og det har vært sagt såpass mye om den svenske byen allerede i diskursen at utsagnet i (8) ikke kan komme som noen overraskelse på adressaten. Innholdet er antatt manifest for adressaten, men blir mer manifest gjennom (8).

$$
\begin{aligned}
& {\left[[ \text { nei vi jeg syns } \quad [ { } ^ { 2 } \mathrm { IKKe } \text { -vi-skal } ] _ { \mathrm { AE } } \quad \mathrm { H } ^ { - } ] _ { \mathrm { FF } } \quad \left[\left[{ }^{1} \text { dra-til-Hudiks }\right]_{\mathrm{AE}}\right.\right.} \\
& \left.\left.\left[{ }^{1} \mathrm{VALL}\right]_{\mathrm{AE}} \mathrm{H}^{-}\right]_{\mathrm{FF}} \text { da-L\% }\right]_{\mathrm{IY}} \\
& \text { (30 år gammel kvinne, Søndre Nordstrand, Oslo) }
\end{aligned}
$$

Når en benektende setning bare består av subjekt, verb og ikke, i den rekkefølgen, vil en fokal frasetone på ikke i kombinasjon med en fokal frasetone på det foregående verbet kunne bety at produsenten påstår at den kontrære positive proposisjonen er usann. I så fall synliggjør $d a$ at (9a) nedenfor uttrykker en negativ proposisjon som presenteres som gjensidig manifest $\mathrm{i}$ den forstand at adressaten burde ha kunnet tenke seg det. En annen mulighet er at adressaten bes bekrefte at den negative proposisjonen er sann. I tillegg kan det være produsentens målsetting å kommunisere på indirekte vis at det er grunn til å tro at subjektreferenten faktisk angrer. Den uttrykte tanken om det motsatte, tillegges adressaten. Denne tolkningen blir enerådende dersom produsenten bruker $a$ istedenfor $d a$. Vidfokusintona-

10 Legg merke til at han som produserer (7), legger trykket på første stavelse av ordet konsert, en vanlig østlandsk og trøndersk behandling som lånord med det standardiserte leksikalske trykket på en senere stavelse kan utsettes for. Dette medfører normalt bruk av aksent 2 på stavelsen med primærtrykket, her ${ }^{2} \mathrm{KON}$ sert. 
sjonen i (9b), hvor verbalfrasen uttømmer ytringens eneste FF, gjør derimot talehandlingen til et entydig informasjonssøkende spørsmål. Innholdet i den negative setningen er resultatet av produsentens slutning, en verbal reaksjon på noe samtalepartneren har sagt.

$$
\begin{array}{ll}
\text { a. } & {\left[\left[\text { han }\left[{ }^{2} \mathrm{ANGrer}\right]_{\mathrm{AE}} \mathrm{H}^{-}\right]_{\mathrm{FF}}\left[\left[^{2} \mathrm{IKKe}\right]_{\mathrm{AE}} \mathrm{H}^{-}\right]_{\mathrm{FF}} \text { da-L\% }\right]_{\mathrm{IY}}} \\
\text { b. } & {\left[\left[\text { han }\left[{ }^{2} \mathrm{ANGrer}-\mathrm{ikke}\right]_{\mathrm{AE}} \mathrm{H}^{-}\right]_{\mathrm{FF}} \text { da-L\% } \%\right]_{\mathrm{IY}}}
\end{array}
$$

\section{Likheter og forskjeller mellom partiklene jo og $d a$}

Modalpartiklene jo og $d a$ har visse leksikalske egenskaper felles. (10), fra NoTa, handler om den amerikanske filmskaperen, samfunnskritikeren og komikeren Michael Moore. Ytringen fungerer som et forsøk fra produsentens side på å få adressaten til å innrømme at mannen har den påståtte egenskapen.

$$
\begin{aligned}
& {\left[\left[\text { men han }\left[{ }^{1} \mathrm{ER}-\mathrm{jo}\right]_{\mathrm{AE}} \mathrm{H}^{-}\right]_{\mathrm{FF}}\left[\left[^{2} \text { veldig }\right]_{\mathrm{AE}}\left[{ }^{2} \mathrm{MORsom}\right]_{\mathrm{AE}} \mathrm{H}^{-}\right]_{\mathrm{FF}}\right. \text { da- }} \\
& \mathrm{L} \%]_{\mathrm{IY}} \\
& \text { (uttalt av den samme mannen som var ansvarlig for (7)) }
\end{aligned}
$$

At Michael Moore er veldig morsom, blir presentert av produsenten som en gjensidig manifest antagelse. Dette skyldes flere språklige fenomen som peker i samme retning som partikkelen $d a$. Midtfeltspartikkelen jo, som er klitisert til det finitte verbet, formidler den prosedurale informasjonen at produsenten anser det for sannsynlig at adressaten og han selv har den samme forutsetningen for å bedømme mannens talent som komiker, og har lik vurdering av ham på det punktet. Ifølge Borthen (2014) signaliserer partikkelen jo «at proposisjonen som modifiseres, er gjensidig manifest for taler og tilhører, samt at proposisjonen skal brukes som premiss for å trekke en slutning» (Borthen 2014: 271).

Når jo og da kombineres $\mathrm{i}$ en ytring (og det gjør de ofte), påvirker de vanligvis den pragmatiske prosesseringen på samme måte som om bare én av dem var blitt brukt, men det finnes semantiske forskjeller mellom dem. Når partikkelen er jo, kan det som gjør den uttrykte tanken gjensidig manifest, være en felles opplevelse av et sanseinntrykk, men det kan også være noe produsenten betrakter som resultatet av et allmenngyldig resonnement som adressaten bør kunne gå med på. De kontekstuelle premissene som $d a$ representerer, er derimot alltid bundet til hva som har skjedd i den umiddelbart foregående delen av diskursen. De ulike typene informasjonskilde knyttet til jo og $d a$ ekskluderer likevel ikke hverandre gjensidig.

Den angitte intonasjonsfraseringen i (10) bygger på mitt auditive inntrykk av hvordan setningen ble uttalt. Denne intonasjonen fungerer like bra dersom (10) bare hadde inneholdt den ene av de to partiklene, enten jo 
eller $d a$. Den viser at ytringens informasjonsfokus er begrenset til produsentens tilordning av sannhetsverdien SANN til den uttrykte proposisjonen. Dette skyldes den høye fokale frasetonen $\mathrm{H}^{-}$på tampen av den første av de to fokale frasene (FF), mens den neste fokale frasen som inneholder det prosodisk prominente predikativet veldig morsom, utgjør den tematiske delen av ytringen. Det diskursgitte temaet er den proposisjonelle formen, uten tilordnet sannhetsverdi, og fokus er påstanden om at det saksforholdet som beskrives, finnes i virkeligheten. Adressaten har tillatt seg å reise tvil om Michael Moores betydelighet. Den adversative konjunksjonen men som åpner (10), knytter seg til det produsenten oppfatter som adressatens reservasjon med hensyn til hvor viktig mannen er som filmskaper og samfunnsrefser. (10) fastslår at det er én ting man ikke kan frata Moore, nemlig hans talent som komiker, og partikkelen $d a$ viser at produsenten regner med at dette må være en felles oppfatning om Moore.

Som nevnt er de to partiklene jo og $d a$ semantisk forskjellige selv om dette kan være usynlig når begge forekommer $\mathrm{i}$ samme ytring. Når det gjelder jo, vektlegger Borthen (2014: 271) at den uttrykte tanken fungerer som gjensidig manifest premiss for å trekke en slutning. Jeg deler denne oppfatningen, men jeg vil tilføye at den formelle forskjellen mellom intonasjon med fokal frasetone på det finitte verbet og intonasjon med fokal frasetone bare i siste setningskonstituent (vidfokus), ikke legger de samme føringene på adressatens pragmatiske bearbeidelse av en ytring som inneholder $j o$. Det ligger et element av overraskelse i jo-modifiserte ytringer som produseres med vidfokusintonasjon, i (11) antagelig fordi produsenten ikke har forbundet subjektreferenten med den nevnte egenskapen og plutselig opplever noe som stemmer dårlig med den tidligere bedømmelsen av mannen.

$$
\left[\left[\text { han er jo }\left[{ }^{2} \mathrm{MORsom}\right]_{\mathrm{AE}} \mathrm{H}^{-}\right]_{\mathrm{FF}} \mathrm{L} \%\right]_{\mathrm{IY}}{ }^{11}
$$

En annen mulighet er at produsenten er overrasket over samtalepartnerens verbale utspill og betoner ved hjelp av jo det opplagte i det som sies i (11). Ytringen kan være en oppfordring til adressaten om å tenke seg om og justere sitt syn på subjektreferenten.

Intonasjonsmønsteret i (12), med to fokale frasetoner fordelt på samme måte som i de tidligere eksemplene på polaritetsfokus, kontekstualiserer annerledes enn vidfokusmønsteret i (11).

$$
\left[\left[\text { han }\left[{ }^{1} \text { ER-jo }\right]_{\mathrm{AE}} \mathrm{H}^{-}\right]_{\mathrm{FF}}\left[\left[^{2} \text { MORsom }\right]_{\mathrm{AE}} \mathrm{H}^{-}\right]_{\mathrm{FF}} \mathrm{L} \%\right]_{\mathrm{IY}}
$$

$11 \mathrm{Her}$ realiseres begge tonene $\mathrm{H}^{-}$og $\mathrm{L} \%$ innenfor den ytringsfinale, trykklette stavelsen som i adjektivet morsom. Derfor høres det en kort stigende tone fulgt av en kort fallende tone innenfor den samme trykklette stavelsen. 
(12) viser at ytringen enten er en innrømmelse overfor en adressat som har forsvart innholdet i ytringen, eller et forsøk på å få adressaten til å innrømme at mannen er morsom. ${ }^{12}$

En viktig forskjell mellom partiklene $d a$ og jo er at jo, i motsetning til $d a$, KODER opplysningen om at produsenten holder den tanken som utsagnssetningen representerer, for å være sann. Jo hører ikke hjemme i interrogativer eller imperativer og kan ikke brukes dersom produsenten tolker den uttrykte tanken som noe en annen person (vanligvis adressaten) tror på, men ikke produsenten selv. I tillegg til at jo hører hjemme $\mathrm{i}$ påstander, $\mathrm{i}$ innrømmelser og $\mathrm{i}$ forsøk på å få adressaten til å innrømme at den uttrykte tanken er sann, vil et etterstilt eksemplar av jo dessuten kunne benyttes $\mathrm{i}$ et ledende spørsmål om bekreftelse, og da antyder partikkelen at den tanken som spørsmålet dreier seg om, allerede er manifest for produsenten, takket være annenhånds informasjon, som i (13), hvor den terminale grensetonen $\mathrm{H} \%$ viser at produsenten ønsker en verbal reaksjon fra en som presumptivt har førstehånds kjennskap til værforholdene $\mathrm{i}$ den aktuelle situasjonen.

\section{$\left[\left[\text { det ble }\left[{ }^{2} \text { TORdenvær }\right]_{\mathrm{AE}} \mathrm{H}^{-}\right]_{\mathrm{FF}} \text { jo-H\%} \%\right]_{\mathrm{IY}}$}

Hvis man erstatter jo med $d a$, er bare den lave grensetonen $d a$ - $\mathrm{L} \%$ tillatt etter utsagnssetningen. Talemålsgrammatikken for norsk tillater høytonevarianten $d a-\mathrm{H} \%$ bare etter imperativer, interrogativer og setningsfragment med spørsmålsfunksjon. (14) er resultatet av en slutning som bygger på tolkning av hva samtalepartneren sa umiddelbart før.

$$
\left[\left[\text { det ble }\left[{ }^{2} \text { TORdenvær }\right]_{\mathrm{AE}} \mathrm{H}^{-}\right]_{\mathrm{FF}} \text { da-L\% }\right]_{\mathrm{IY}}
$$

Jo, med $\mathrm{H} \%$ eller L\%, kan ikke brukes i en konklusjon som er basert utelukkende på innholdet i samtalepartnerens siste replikk, som i (14). Når partikkelen er jo, bygger ikke den uttrykte tanken om været på informasjon fra adressaten som produsenten har aktivert og gjør bruk av i sitt arbeidsminne. Erstatter vi $d a$ i (14) med jo-L\%, blir ytringen et uttrykk for en erkjennelse som kan skyldes direkte persepsjon i ytringsøyeblikket.

Talehandlingspotensialet for en språklig stimulus som (15) med prosodisk polaritetsfokus på verbet kombinert med partikkelen $d a$ er rikere enn når ytringen inneholder kun én FF som uttømmer utsagnssetningen, som i (14).

12 Når jo opptrer som etterstilt partikkel med grensetonen L\% og og ytringen er utstyrt med vidfokusintonasjon, er det nærliggende å slutte at produsenten er overrasket. Her skiller norsk og svensk tale lag. Jeg har observert i flere situasjoner at det svenske motstykket $j u$ etter en utsagnssetning som blir uttalt med vidfokusintonasjon, kan brukes når produsenten innrømmer at proposisjonen er sann. I norsk talespråk er slik bruk av etterstilt jo umulig. 


$$
\left[\left[\operatorname{det}\left[{ }^{1} \mathrm{BLE}\right]_{\mathrm{AE}} \mathrm{H}^{-}\right]_{\mathrm{FF}}\left[\left[^{2} \mathrm{TORdenvær}\right]_{\mathrm{AE}} \mathrm{H}^{-}\right]_{\mathrm{FF}} \text { da-L\% }\right]_{\mathrm{IY}}
$$

(15) kan benyttes for å utføre en påstand når en slik forståelse ser ut til å gi best mening. Da er det produsentens egen tanke som formidles, en tanke som presumptivt er mer manifest for produsenten enn for adressaten, som kanskje trenger å bli eksplisitt opplyst om at det trakk opp til uvær. I en annen kontekst kan en ytring av (15) være et spørsmål om produsenten har trukket den rette slutningen. Da presenterer produsenten innholdet som klarest manifest for adressaten, og den metarepresenterte tanken er adressatens tanke, slik den oppfattes av produsenten. Bruken av prosodisk polaritetsfokus på verbet og i tillegg framheving av det diskursgitte nominalet tordenvaer oppfatter jeg da som en konvensjonell form for imitasjon av et intonasjonsmønster produsenten ser for seg at adressaten kunne ha brukt på det aktuelle punktet i samtalen, den samme kombinasjonen av syntaktisk og prosodisk form som om adressaten selv hadde bekreftet at det ble tordenvær.

Til nå har ingen av de intonasjonstranskriberte ytringene i de tidligere avsnittene inneholdt et fokalt aksentuert subjekt i setningsinitial posisjon. Når intonasjonen er som vist i (16), kan det være et poeng for produsenten å trekke fram den mannlige referenten som et unntak blant andre, mindre morsomme folk, men produsenten forutsetter samtidig at adressaten er enig. Det siste skyldes begge partiklene jo og $d a$, men med jo i midtfeltet i (16) blir det nok lettere å slutte at produsenten ønsker en innrømmelse fra adressaten, som i (10) fra NoTa-korpuset.

$$
\begin{aligned}
& {\left[\left[{ }^{1} \mathrm{HAN}\right]_{\mathrm{AE}} \mathrm{H}^{-}\right]_{\mathrm{FF}}\left[\left[^{1} \mathrm{er}-\mathrm{jo}\right]_{\mathrm{AE}}\left[{ }^{2} \text { veldig }\right]_{\mathrm{AE}}\left[{ }^{2} \mathrm{MORsom}\right]_{\mathrm{AE}} \mathrm{H}^{-}\right]_{\mathrm{FF}} \text { da- }} \\
& \mathrm{L} \%]_{\mathrm{IY}}
\end{aligned}
$$

$D a$ blokkerer ikke en forståelse av ytringen som spørsmål, men krever det heller ikke, så det foreligger ingen intern kontradiksjon i (16) mellom hva jo formidler og hva $d a$ formidler. På grunn av partikkelen jo plassert i midtfeltet blir en tolkning av (16) som informasjonssøkende spørsmål uaktuell.

Borthen (2014) hevder at hypotesen, i (3), om at $d a$ presenterer innholdet $i$ en ytring som gjensidig manifest, er utilstrekkelig fordi det vil bety at semantikken til $d a$ settes lik semantikken til jo. Hun illustrerer den semantiske forskjellen mellom $d a$ og jo med dataene i (17), en replikkveksling mellom $\mathrm{A}$ og B, der B1-B3 er alternative svar på spørsmålet til A.

(17) [Kontekst: Tilhører er ikke oppmerksom på at han har smuler over hele genseren, men kan lett oppdage dette om han kikker ned på genseren sin.]

A: $\quad$ Synes du jeg spiser stygt? 
B1: Ja. ?Du har smuler over hele genseren, da.

B2: Ja. Du har smuler over hele genseren.

B3: Ja. Du har jo smuler over hele genseren.

(Borthen 2014: 271)

Ifølge Borthen er hennes utgave B3 med partikkelen jo relevant som reaksjon på spørsmålet til A. Den partikkelløse utgaven B2 blir og relevant, som angivelse av en premiss som grunnlag for det positive svaret $J a$, men det vil være unaturlig å benytte den etterstilte partikkelen $d a$ i B1 for å besvare det samme spørsmålet, sier hun. I en sluttnote som angår hennes eksempel (17) B1 (note 9 på s. 302 i Borthen 2014), finnes følgende kommentar: «Jeg antar at alle ytringene i (17) uttales med fokal aksent på 'genseren', og at dette er den eneste fokale aksenten i ytringen.»> ${ }^{13}$ Hun stipulerer altså en intonasjonsstruktur med hele verbalfrasen som fokus. Med bruk av Trondheimsmodellens konvensjoner for annotering av den hierarkiske oppbygningen av østnorsk intonasjonsstruktur, blir intonasjonen i B1 som vist i (18), og dette er, som Borthen riktig bemerker, en form som passer dårlig i et svar på det spørsmålet $\mathrm{A}$ har stilt.

$$
\begin{aligned}
& \text { Ja. \#[[du har } \left.\left[{ }^{2} \text { smuler-over }\right]_{\mathrm{AE}}\left[{ }^{2} \text { hele }\right]_{\mathrm{AE}}\left[{ }^{2} \text { GENseren }\right]_{\mathrm{AE}} \mathrm{H}^{-}\right]_{\mathrm{FF}} \text { da- } \\
& \mathrm{L} \%]_{\mathrm{IY}}
\end{aligned}
$$

Når produsentens informasjonsfokus omfatter innholdet i sin helhet, som i (18), blir innholdet gjensidig manifest bare dersom vi antar at produsenten ønsker å få bekreftet at genseren er full av smuler, men dette vil være et irrelevant svar på spørsmålet til $\mathrm{A}$. Talehandlingen må være en påstand, en opplysning som støtter den positive responsen $\mathrm{Ja}$. Dette er uproblematisk om man endrer litt på intonasjonsfraseringen i forhold til den lite passende strukturen i (18). Både (19) og (20) viser hensiktsmessige kombinasjoner av syntaks og prosodi i den diskursrammen som foreligger i (17).

$$
\begin{aligned}
& \text { Ja. }\left[\left[\mathrm{du} \text { har }\left[{ }^{2} \text { SMUler-over }\right]_{\mathrm{AE}} \mathrm{H}^{-}\right]_{\mathrm{FF}}\left[\left[^{2} \text { hele }\right]_{\mathrm{AE}}\left[{ }^{2} \text { GENseren }\right]_{\mathrm{AE}} \mathrm{H}^{-}\right]_{\mathrm{FF}}\right.
\end{aligned}
$$

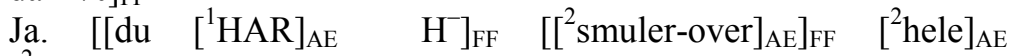

$$
\begin{aligned}
& \left.\left.\left[{ }^{2} \mathrm{GEN} \text { seren }\right]_{\mathrm{AE}} \mathrm{H}^{-}\right]_{\mathrm{FF}} \text { da-L\% } \%\right]_{\mathrm{IY}}
\end{aligned}
$$

(20) illustrerer regulær bruk av polaritetsfokus, formelt uttrykt som utheving av det finitte verbet. Den uttrykte proposisjonen er ytringens tema og den fokale frasetonen på verbet skyldes at denne proposisjonen påstås å være sann, i pakt med det avgitte positive svaret $J a$. Intonasjonsfraseringen i (19) er litt annerledes, men i likhet med (20) inneholder ytringen to fokale fraser

13 Eksempelet er tilfeldigvis (17) ikke bare i denne artikkelen, men også hos Borthen (2014).

14 \# betyr at setningen ikke passer inn i diskurssammenhengen. 
(FF). Nominalet smuler er gjort prosodisk prominent i (19) og utgjør ytringens fokus, mens den neste prosodisk prominente frasen er nominalet hele genseren. Adressaten $\mathrm{A}$ blir gjort oppmerksom på alle smulene på genseren, et plagg som fungerer som informasjonsstrukturell bakgrunn, men som like fullt kan utstyres med den fokale frasetonen $\mathrm{H}^{-}$på slutten av siste FF.

Konklusjonen blir at B1 i (17) avviker fra normal norsk tale bare dersom man lar ett bestemt intonasjonsmønster dekke syntagmet, nemlig vidfokusmønsteret i (18). Kanskje er det ikke partikkelen $d a$ det er noe galt med i (17), men snarere den stipulerte vidfokusintonasjonen. Det finnes uansett slående funksjonelle forskjeller mellom jo og $d a$.

Den informasjonen som en intonasjonsstruktur formidler i interaksjon med andre prosedurale indikatorer («cues») er ikke en auditiv refleks av noe som har sitt semantiske innhold representert $i$ en annen del av grammatikken. Borthen (2014: 272-274) foreslår en sammensatt leksikalsk semantikk for partikkelen $d a$ i ekstraponert posisjon. Hennes forslag tar hensyn til de fleste av de mulighetene som en produsent har for å nyansere sitt budskap ved hjelp av $d a$, og som en adressat er nødt til å velge mellom i møtet med en ytring som modifiseres av denne modalpartikkelen. Jeg for min del vektlegger intonasjonens rolle som prosedural indikator i samspill med partikkelen. Det er ikke partikkelens leksikalske semantikk alene som gjør språkbrukeren i stand til å reagere adekvat på en gitt forekomst av da i en gitt samtalesituasjon. Partikkelens bidrag til økt relevans må betraktes $\mathrm{i}$ relasjon til andre indikatorer som forteller noe om hvordan dens pragmatiske rolle skal forstås i det enkelte tilfellet. Den språklige kombinasjonen av partikkel, intonasjon og deklarativ setningstype avgrenser adressatens søk innenfor rammen av tilgjengelige tanker om hvordan produsenten har hatt til hensikt å påvirke adressatens slutninger. Det er denne helheten som kan forventes å bidra til å øke ytringens relevans, primært gjennom kutt i prosesseringskostnadene for adressaten. Partikkelen $d a$ koder ikke på egen hånd informasjon som klargjør for adressaten om produsent og adressat er enige eller uenige om den tanken som setningen representerer, den koder ikke informasjon om hva slags talehandlingstype som utføres, og den forteller ikke om den uttrykte tanken befinner seg innenfor eller utenfor den mengden av forestillinger om verden som utgjør produsentens mentalt aktiverte kontekst.

\section{$a$ lar seg ikke kombinere med andre modalpartikler}

Nær beslektet med bruken av partikkelen $d a$ i spørsmål om bekreftelse er den bruksmåten som tillater at partikkelen $a$ framstår som et adekvat alternativ. Dette er en partikkel med et bruksområde som gjør at $d a$ kunne ha gjort samme nytte i nøyaktig samme mentale kontekst, men $a$ begrenser søket etter den intenderte tolkningen ved at adressaten bes se bort fra muligheten for at ytringen er ment å fungere som påstand eller som et helt 
ordinært spørsmål om bekreftelse. Bortfallet av den konsonanten som finnes både i det anaforiske adverbet $d a$ og i den segmentalt identiske partikkelen, anser jeg for å være et ikonisk trekk som peker på det faktum at den kognitive sammenhengen mellom innholdet i vertskapssetningen og den mentale konteksten som partikkelen representerer, er brutt. Den utpreget muntlige partikkelen $a$ som erstatning for $d a$ opplyser nettopp om misforholdet mellom den tanken som uttrykkes, og den mentale konteksten som produsenten baserer sine uttrykte tanker om samtaletemaet på. Fordi $a$, i motsetning til $d a$, er en partikkel med entydige pragmatiske konsekvenser etter en utsagnssetning, vil denne konsonantløse utgaven kunne gjøre prosesseringen kortere for den som har en intuitiv kjensle for distinksjonen mellom $d a \operatorname{og} a$.

Det formelt poengterte skillet mellom den proposisjonen som uttrykkes, og produsentens forestilling om at den er usann og at adressatens oppfatning derfor ikke holder vann, er et kodet element i norske talemålskonstruksjoner der en utsagnssetning modifiseres av $a$. Når $a$ er appendiks til en utsagnssetning, kreves både bruk av polaritetsfokus i IY'ens første FF og fokal aksentuering $\left(\mathrm{H}^{-}\right)$for å angi temafrasen i neste FF. Det knytter seg følgelig sterkere restriksjoner til rett bruk av $a$ enn til rett bruk av $d a$, både semantisk og formelt.

(21)-(24') viser at bruk av $a$ er inkompatibel med bruk av modalpartikler som vel og jo.

$$
\begin{aligned}
& {\left[\left[\operatorname{det}\left[{ }^{1} \mathrm{BLE}\right]_{\mathrm{AE}} \mathrm{H}^{-}\right]_{\mathrm{FF}}\left[\left[^{2} \mathrm{TORdenvær}\right]_{\mathrm{AE}} \mathrm{H}^{-}\right]_{\mathrm{FF}} \mathrm{a}-\mathrm{L} \%\right]_{\mathrm{IY}}} \\
& \left.\left[\left[\operatorname{det}\left[{ }^{1} \mathrm{BLE}-\mathrm{vel}\right]_{\mathrm{AE}} \mathrm{H}^{\mathrm{FF}}\right]_{\mathrm{FF}}\left[{ }^{2} \mathrm{TORdenvær}\right]_{\mathrm{AE}} \mathrm{H}\right]_{\mathrm{FF}} \mathrm{da}-\mathrm{L} \%\right]_{\mathrm{IY}} \\
& *\left[\left[\operatorname{det}\left[{ }^{1} \mathrm{BLE}-\mathrm{Bel}\right]_{\mathrm{AE}} \mathrm{H}^{-}\right]_{\mathrm{FF}}\left[\left[^{2} \mathrm{TORdenvær}\right]_{\mathrm{AE}} \mathrm{H}^{-}\right]_{\mathrm{FF}} \mathrm{a}-\mathrm{L} \%\right]_{\mathrm{IY}} \\
& {\left[\left[\text { han }\left[{ }^{1} \mathrm{ER}\right]_{\mathrm{AE}} \mathrm{H}^{-}\right]_{\mathrm{FF}}\left[\left[^{2} \mathrm{MORsom}\right]_{\mathrm{AE}} \mathrm{H}^{-}\right]_{\mathrm{FF}} \mathrm{a}-\mathrm{L} \%\right]_{\mathrm{IY}}} \\
& {\left[\left[\text { han }\left[{ }^{1} \mathrm{ER}-\mathrm{jo}\right]_{\mathrm{AE}} \mathrm{H}^{-}\right]_{\mathrm{FF}}\left[\left[^{2} \mathrm{MORsom}\right]_{\mathrm{AE}} \mathrm{H}^{-}\right]_{\mathrm{FF}} \text { da-L\% }\right]_{\mathrm{IY}}} \\
& *\left[\left[\text { han }\left[{ }^{1} \mathrm{ER}-\mathrm{jo}\right]_{\mathrm{AE}} \mathrm{H}^{-}\right]_{\mathrm{FF}}\left[\left[^{2} \mathrm{MORsom}\right]_{\mathrm{AE}} \mathrm{H}^{-}\right]_{\mathrm{FF}} \mathrm{a}-\mathrm{L} \%\right]_{\mathrm{IY}}
\end{aligned}
$$

Partikkelen vel i det syntaktiske midtfeltet i (22)/(22') røper en viss usikkerhet, men produsenten signaliserer likevel at den uttrykte tanken er svakt manifest og ber tilsynelatende adressaten bekrefte at det satte inn med tordenvær. Dette fungerer greit om partikkelen er $d a$, som i (22), men det motsies av $a \mathrm{i}\left(22^{\prime}\right)$, som viser at produsenten er innstilt på å få adressaten til å tenke over om det finnes noe bevis for at det oppsto tordenvær på det aktuelle stedet og tidspunktet. Den semantiske konflikten mellom de to partiklene vel og a gjør at (22') ikke bare blir inkoherent, men også ugrammatisk. I (21) er a eneste modalpartikkel, og med prosodisk polaritetsfokus på plass i vertskapssetningen ligger alt til rette for at adressaten vil forstå at produsenten mistenker at det ikke ble noe tordenvær, den motsatte oppfatningen av adressatens.

Partiklene jo og $a$ ekskluderer hverandre gjensidig på samme måte som vel og $a$. $A$ i (23) sår tvil om mannens evner som moromann. Jo i (24') 
kommuniserer at produsenten framstiller det som gjensidig manifest at den det refereres til, er en morsom fyr, men partikkelen $a$ innebærer en avvisning av den betraktningen. Ingen kontekst vil kunne rettferdiggjøre en kombinasjon av de to modalpartiklene jo og $a$ i norsk tale, så i likhet med $\left(23^{\prime}\right)$ er (24') en ugrammatisk språklig struktur. (24), med $d a$ som appendiks, uttrykker derimot en grammatisk velformet påstand, liksom (10) fra NoTa-korpuset.

Midtfeltspartikkelen $d a$ kan heller ikke opptre sammen med $a$. Takket være midtfeltspartikkelen $d a$ er (25) en entydig påstand som ser ut til å motsi adressatens oppfatning. (26) er ugrammatisk på grunn av inkompatible leksikalske trekk hos de to partiklene. $A$ er ikke forenlig med talehandlingen påstand.

$$
\begin{aligned}
& {\left[\left[\text { han }\left[{ }^{1} \text { ER-da }\right]_{\mathrm{AE}} \mathrm{H}^{-}\right]_{\mathrm{FF}}\left[\left[^{2} \text { MORsom }\right]_{\mathrm{AE}} \mathrm{H}^{-}\right]_{\mathrm{FF}} \text { da-L\% }\right]_{\mathrm{IY}}} \\
& *\left[\left[\text { han }\left[{ }^{1} \text { ER-da }\right]_{\mathrm{AE}} \mathrm{H}^{-}\right]_{\mathrm{FF}}\left[\left[^{2} \text { MORsom }\right]_{\mathrm{AE}} \mathrm{H}^{-}\right]_{\mathrm{FF}} \mathrm{a}-\mathrm{L} \%\right]_{\mathrm{IY}}
\end{aligned}
$$

Lista over modalpartikler som ikke lar seg kombinere med $a$, omfatter også visst og nok. Begge viser en usikkerhet hos produsenten som ikke hører hjemme $i$ en metarepresentasjon av tanker som ikke passer med produsentens eget syn på verden.

(10), fra NoTa-korpuset, var en påstand og samtidig et forsøk på å få adressaten til å innrømme at det forholder seg sånn som produsenten sier. Som nevnt utelukker partikkelen $a$ at talehandlingen kan være en påstand. Den tanken som uttrykkes ved hjelp av vertskapssetningen, står i kontrast til den mentale konteksten som $a$ representerer, og som produsenten selv forholder seg til. Enhver forekomst av en utsagnssetning som modifiseres av $a$, er et uttrykk for at produsenten er uenig med adressaten, men diskrepansen kommuniseres på implisitt vis, som implikatur (Grice 1989; Carston 1988, 2002). På det eksplisitte planet fungerer utsagnssetninger etterfulgt av partikkelen $a$ som ledende spørsmål, men hintet om manglende samsvar mellom de to partenes syn på den uttrykte proposisjonen, penser adressatens tanker inn på et spor som gjør det klart at produsenten vil noe annet enn å få en bekreftelse på at setningen beskriver et saksforhold som stemmer med virkeligheten.

\section{Pragmatisk analyse av da og a under varierende lingvistiske og kontekstuelle forhold}

\section{En liten akseptabilitetstest}

Som forberedelse til den analysen som presenteres i tidligere avsnitt, foretok jeg en akseptabilitetstest der to auditive stimuli inneholdt partikkelen $a$ med den terminale grensetonen L\%. Grunntanken var at ingen nordmann har problem med partikkelen $d a$ i samme posisjon, men $a$ har både dialektale og sosiolektale begrensninger, og jeg ønsket å finne ut hvor godt integrert de 
bruksvilkårene som gjelder for $a$, er i folks bevissthet. $A$ tilhører ikke det svensker kaller «vårdat språk», så hos den som er preskriptivist, er det grunn til å tro at $a$ ikke har særlig høy kurs. Ytringer av setningen Du hadde dem med deg da du gikk hjemmefra, a?, hvor partikkelen $a$ indikerer at talehandlingen skal oppfattes som et adversativt spørsmål, ble produsert med to forskjellige intonasjonsfraseringer, her gjengitt visuelt $\mathrm{i}$ form av de to grunntonekonturene i henholdsvis Figur 1 og Figur 2 nedenfor. Jeg sikret meg samarbeid med 16 respondenter som jeg antok ville være fortrolige med partikkelen $a$ fordi hverdagstalemålet deres har et umiskjennelig sørøstnorsk preg med typisk uformelle innslag. Halvparten, åtte personer, fikk høre ytringen med intonasjonskonturen i Figur 1 før den i Figur 2. Den andre halvparten fikk høre dem i motsatt rekkefølge.

Det viste seg at ingen av de 16 respondentene godtok kombinasjonen av morfosyntaks og vidfokusintonasjon i Figur 1, mens 15/16 godtok møtet mellom morfosyntaks og intonasjonsfrasering i Figur 2, hvor det er polaritetsfokus på verbformen hadde og en ny fokal frasetone som framhever det tematiske adverbialet hjemmefra. Dette resultatet støtter mitt intuitive inntrykk at partikkelen $a$ etter en utsagnssetning ikke er forenlig med vidfokusintonasjon, og at en intonasjon med to FF, først én som gjør ytringens informasjonsfokus prosodisk prominent og deretter én som gjør ytringens temafrase prosodisk prominent, må til for å skape et velformet resultat.

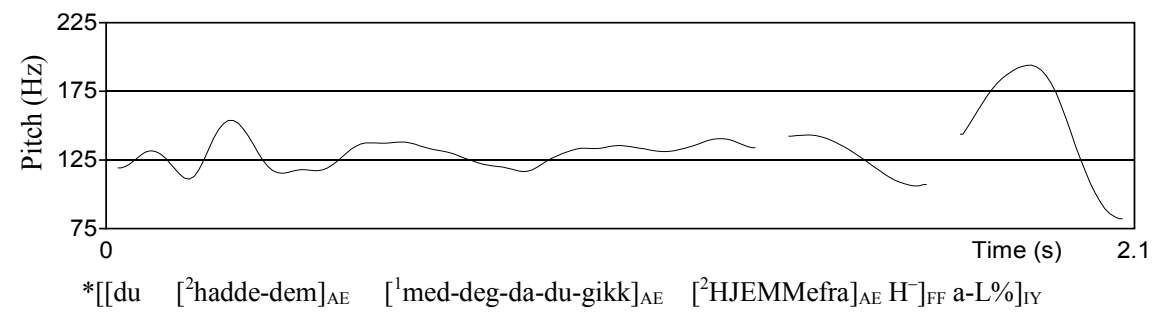

Figur 1.

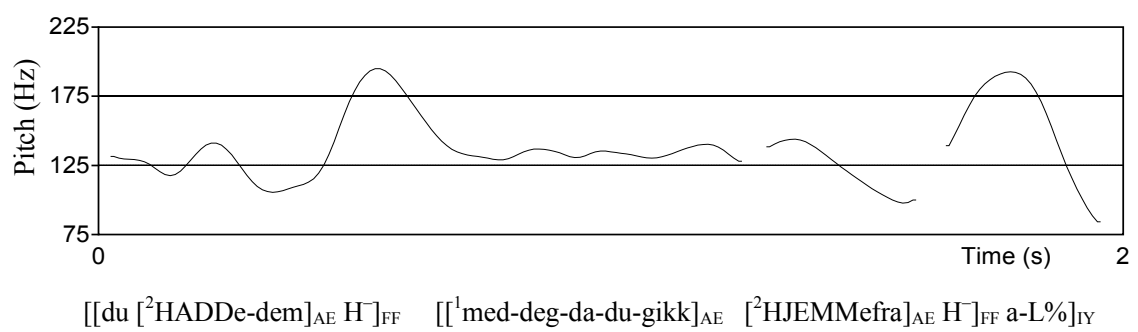

Figur 2. 


\section{Illustrasjon av hvordan de respektive semantiske betydningene til $\mathrm{da}$ og $a$ får forskjellige grammatiske og pragmatiske konsekvenser}

I dette avsnittet ser jeg nærmere på hvordan setningen og grunntonekonturene i Figur 1 og Figur 2 gir retningslinjer for adressatens pragmatiske prosessering av ytringer som produseres som respons på et utsagn fra samtalepartneren. Dessuten har jeg tilføyd en replikkveksling, i (28), der polariteten i setningen som B reagerer på, er endret fra positiv til negativ. Partikkelposisjonen er fylt med $d a$ i (27) og med $a$ i (27'). Akseptabilitetsbedømmelsene er mine, men fordelingen av grammatisk og ugrammatisk møte mellom syntaks og intonasjon samsvarer med de vurderingene som forrige avsnitt handlet om. Der hvor B's verbale respons er markert med \#, er strukturen grammatisk velformet, men ikke relevant som reaksjon på utsagnet til A (gjelder bare for $\left(27^{\prime}\right) \operatorname{og}(28)$ ).

$$
\begin{aligned}
& \text { A: Jeg må ha lagt igjen solbrillene et sted, kanskje på den kaféen. } \\
& \text { B1: [[du }\left[{ }^{2} \text { hadde-dem }\right]_{\mathrm{AE}}\left[{ }^{1} \text { med-deg-da-du-gikk }\right]_{\mathrm{AE}}\left[{ }^{2} \mathrm{HJEMMefra}\right] \\
& \left.\left.{ }_{\mathrm{AE}} \mathrm{H}^{-}\right]_{\mathrm{FF}} \mathrm{da}-\mathrm{L} \%\right]_{\mathrm{IY}} \\
& \text { B2: }\left[\left[\mathrm{du} \quad\left[{ }^{2} \mathrm{HADDe}-\mathrm{dem}\right]_{\mathrm{AE}} \quad \mathrm{H}^{-}\right]_{\mathrm{FF}} \quad\left[{ }^{1} \text { med-deg-da-du-gikk }\right]_{\mathrm{AE}}\right. \\
& \left.\left.\left[{ }^{2} \mathrm{HJEMMefra}\right]_{\mathrm{AE}} \mathrm{H}^{-}\right]_{\mathrm{FF}} \text { da-L\% }\right]_{\mathrm{IY}} \\
& \text { B3: [[du } \left.\left[{ }^{2} \mathrm{HADDe}-d e m-i k k e\right]_{\mathrm{AE}} \mathrm{H}^{-}\right]_{\mathrm{FF}}\left[{ }^{1} \text { med-deg-da-du-gikk }\right]_{\mathrm{AE}} \\
& \left.\left.\left[{ }^{2} \mathrm{HJEMMefra}\right]_{\mathrm{AE}} \mathrm{H}^{-}\right]_{\mathrm{FF}} \text { da-L\% }\right]_{\mathrm{IY}}
\end{aligned}
$$

Av de tre alternative svarene B1, B2 og B3 på utsagnet til A i (27), har vidfokusstrukturen i B1 det mest restriktive talehandlingspotensialet. (27) $\mathrm{B} 1$ viser at det $\mathrm{i}$ ytringsøyeblikket er manifest for B at A hadde solbrillene sine med seg da A forlot boligen sin. Det er ingen ting ved den ytringen som tilsier at B betviler dette. B ønsker likevel at A eksplisitt bekrefter at det forholder seg slik. B1 metarepresenterer A's syn på saken, slik B tolker A. Å påstå at $\mathrm{A}$ hadde brillene med seg hjemmefra, ville ha vært en irrelevant talehandling fra B's side, for det A sier, forutsetter dette. Vidfokusintonasjonen i B1, der én FF dekker hele den deklarative setningen, ville likevel ha gjort talehandlingen til en påstand dersom B hadde sløyfet partikkelen $d a$. At B anser den uttrykte tanken for å være gjensidig manifest, samsvarer med det metarepresenterte innholdet i setningen og det settet av kontekstuelle premisser som $d a$ representerer i (27), men ettersom svaret på B's spørsmål om bekreftelse allerede er gitt om man tar A's uttrykte tanker på alvor, blir konklusjonen at (27) B1 ikke er en utpreget relevant ytring.

I likhet med (27) B1 ber også (27) B2 adressaten teste idéen om at den tanken som er uttrykt i vertskapssetningen, er gjensidig manifest. Partikkelen viser dette. Kombinasjonen av deklarativ setning, da og B's intonasjonsfrasering kunne ha pekt $\mathrm{i}$ retning av at $\mathrm{B}$ utfører en påstand ved hjelp av B2. På den annen side viser innholdet $\mathrm{i}$ ytringen til $\mathrm{A}$ at en opplysning om at A tok med seg solbrillene hjemmefra, ville være totalt 
irrelevant. Det finnes én eneste lesning som gjør B2 relevant. Talehandlingen i B2 er et spørsmål rettet til A, men det er en annen type spørsmål enn det som utføres i B1. Det som skjer i B2, er at B benytter en setning som uttrykker en tanke $\mathrm{B}$ selv ikke går god for. Her får testingen $\mathrm{av}$ hypotesen om at den uttrykte tanken er gjensidig manifest, et negativt utfall. $\mathrm{B}$ bruker et intonasjonsmønster i (27) B2 som må forstås som en imitasjon av et mønster A godt kunne ha brukt $\mathrm{i}$ en ytring som forsikrer om at solbrillene var med da A forlot boligen sin. B2 blir mer relevant enn B1 dersom B2 forstås som en metarepresentasjon av hvordan A tenker om saken, i motsetning til hvordan B tenker. Innholdet presenteres fra en synsvinkel som ikke er B's egen, men tvert imot samtalepartneren A's.

(27) B2 gjenspeiler A's oppfatning av de faktiske forhold i valget av konseptuelt innhold og i valget av intonasjonsstruktur, men interessant nok ikke i valget av modalpartikkelen $d a$. Forutsetningen for at $\mathrm{B} 2$ framstår som en relevant verbal reaksjon på det $\mathrm{A}$ sier, er at partikkelen representerer en kontekst som B forholder seg til i ytringsøyeblikket, men som imøtegår den tolkningen av A's tanker som uttrykkes i vertskapssetningen, noe den leksikalske instruksen i (3) tar høyde for. Det foreligger altså et bevisst uttrykt epistemisk misforhold mellom den uttrykte tanken og de kontekstuelle premissene som partikkelen $d a$ representerer. B aksepterer ikke den konteksten som A legger til grunn. B2 fungerer følgelig som en oppfordring til A om å revurdere sin tro på at solbrillene kan være gjenglemt et sted utenfor hjemmet til A. Den eksplisitt utførte talehandlingen er et spørsmål, men det er et adversativt spørsmål som synliggjør en uenighet mellom de to samtalende partene.

(27) B3 uttrykker det negative motstykket til det kognitive innholdet i B1 og B2. Her er det åpenbart B’s egen erindring om de faktiske forhold som beskrives i den negative vertskapssetningen til partikkelen. B mener å vite at A lot solbrillene ligge igjen hjemme. B3 blir derfor en påstand som avviser tanken om at de kan være lagt igjen et sted ute i byen. A og B har forskjellige oppfatninger om hvor solbrillene til A befinner seg. Setningen og intonasjonen har en form som ville ha fungert fint for et adversativt spørsmål à la det i (27) B2, men konteksten er ikke forenlig med en forestilling om at B utfører et adversativt spørsmål. Ingen implikatur som strider mot negasjonen, blir kommunisert her. B tror på innholdet $\mathrm{i}$ den negative vertskapssetningen og kommuniserer sin oppfatning i B3.

La oss nå sammenligne (27) og $\left(27^{\prime}\right)$. (27') er identisk med (27), med unntak av at partikkelen ikke er $d a$, men $a$.

(27') A: Jeg må ha lagt igjen solbrillene et sted, kanskje på den kaféen. $\mathrm{B} 1: *\left[\left[\mathrm{du}\left[{ }^{2} \text { hadde-dem }\right]_{\mathrm{AE}}\left[{ }^{1} \text { med-deg-da-du-gikk }\right]_{\mathrm{AE}}\left[{ }^{2} \mathrm{HJEMMefra}\right]\right.\right.$ $\left.\left.{ }_{\mathrm{AE}} \mathrm{H}^{-}\right]_{\mathrm{FF}} \mathrm{a}-\mathrm{L} \%\right]_{\mathrm{IY}}$

$\mathrm{B} 2:\left[\left[\mathrm{du}\left[{ }^{2} \mathrm{HADDe}-\mathrm{dem}\right]_{\mathrm{AE}} \mathrm{H}^{-}\right]_{\mathrm{FF}}\left[\left[{ }^{1} \text { med-deg-da-du-gikk }\right]_{\mathrm{AE}}\left[{ }^{2} \mathrm{HJE}\right.\right.\right.$ MMefra $\left.]_{\mathrm{AE}} \mathrm{H}^{-}\right]_{\mathrm{FF}}$ a-L\% $]_{\mathrm{IY}}$ 
B3: \#[[du $\left.\left[{ }^{2} \mathrm{HADDe}-d e m-i k k e\right]_{\mathrm{AE}} \mathrm{H}^{-}\right]_{\mathrm{FF}}\left[{ }^{1} \text { med-deg-da-du-gikk }\right]_{\mathrm{AE}}$ $\left.\left[{ }^{2} \mathrm{HJEMMefra}\right]_{\mathrm{AE}} \mathrm{H}^{-}\right]_{\mathrm{FF}}$ a-L\% $]_{\mathrm{IY}}$

Resultatet av den tidligere omtalte akseptabilitetstesten viser at vi trygt kan fastslå at valget av $a$ på bekostning av $d a$ gjør (27') B1 ugrammatisk på grunn av kombinasjonen av vidfokusintonasjon og $a$ (jf Figur 1). Den leksikalske semantikken til $a$ innebærer at denne partikkelen ikke hører hjemme i et spørsmål om bekreftelse på noe adressaten antas å ha sikrere viten om enn spørsmålsstilleren. Partikkelen $a$ indikerer at talehandlingen er et adversativt spørsmål, men vidfokusintonasjonen strider mot den tolkningen. Fordi $d a$ er erstattet med $a$, blir også (27') B3 en meningsløs ytring som reaksjon på talehandlingen til $\mathrm{A}$, men språkstrukturen er ikke ugrammatisk sånn som i B1, for den vil være helt adekvat i noen kontekster. Den uttrykte tanken ser ut til å stride mot innholdet i ytringen til A, og ville ha kunnet fungere som en påstand som avviser oppfatningen til $\mathrm{A}$, hvis det ikke hadde vært for at partikkelen er $a$, ikke $d a$ som i (27) B3. Partikkelen $a$ gir beskjed om at B kommuniserer at A faktisk hadde med seg solbrillene. Problemet med den tolkningen av ytringen til B er at et slikt innhold i realiteten er i full overensstemmelse med hva A selv har sagt. Partikkelen $a$ må gi ytringen et preg av at det foreligger et epistemisk misforhold mellom A's og B's respektive virkelighetsbeskrivelser. En slik uttrykt motsetning mangler i (27') B3.

Modalpartikkelen $a$ representerer uten unntak en kontekst som er B's egen, og som strider mot B's tanker om innholdet i utsagnssetningen. Av de tre svarene i $\left(27^{\prime}\right)$ er det bare B2 som tilfredsstiller dette kravet. Den ytringen illustrerer kontrasten mellom de respektive virkelighetsoppfatningene til A og B. (27') B2 er ekvivalent med (27) B2, der partikkelen var $d a$. Forskjellen mellom dem består i at (27) B2 blir oppfattet som et adversativt spørsmål fordi dette synes å være den mest relevante tolkningen, mens (27') B2 er et adversativt spørsmål fordi den lingvistiske formen med partikkelen $a$ ifølge den leksikalske tilleggsinstruksen i (4) ikke tillater noen annen tolkning. B2 er en oppfordring til A om å revurdere gyldigheten til den konteksten som ville ha gjort ytringen til A sann og relevant, både i (27) og i (27'). Med andre ord, den som ytrer B2 i $(27) /\left(27^{\prime}\right)$, ber A endre sine kontekstuelle premisser i samsvar med B's kommuniserte tvil, en tvil om hvorvidt A's hukommelse er til å stole på. Partikkelen $a$ kontekstualiserer på en mer restriktiv måte enn den partikkelen som har samme segmentale form som det anaforiske adverbet $d a$. Når $d a$ står som syntaktisk appendiks, er det pragmatiske slutninger som avgjør om talehandlingen er et adversativt spørsmål som setter adressatens oppfatning opp mot produsentens. Når partikkelen er $a$, stilles det derimot som kontekstuavhengig semantisk krav at produsenten tror adressaten holder den uttrykte tanken for å være sann, mens produsenten resonnerer med utgangspunkt $i$ en mental kontekst som ikke er forenlig med 
adressatens. Et slikt resultat av den pragmatiske prosesseringen kan være det rette også dersom partikkelen er $d a$. Forslaget til prosedural semantikk for $d a$ i (3) nevner nettopp muligheten for at det mest relevante resultatet av prosesseringen blir at den tanken vertskapssetningen uttrykker, ikke deles av produsenten. (27) B2 illustrerer dette.

I (28) har replikken til A et annet innhold enn i $(27) /\left(27^{\prime}\right)$. Den eneste relevante responsen er B2, som skiller seg fra B3 utelukkende i valget av partikkel.
A: Jeg tok ikke med meg solbriller i dag.
B1: \#[[du $\quad\left[{ }^{2} \text { hadde-dem }\right]_{\mathrm{AE}} \quad\left[{ }^{1} \text { med-deg-da-du-gikk }\right]_{\mathrm{AE}}$ $\left.\left[{ }^{2} \text { HJEMMefra] }{ }_{A E} \mathrm{H}^{-}\right]_{\mathrm{FF}} \mathrm{da}-\mathrm{L} \%\right]_{\mathrm{IY}}$

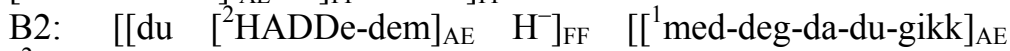 ${ }^{2}$ HJEMMefra $\left.]_{\mathrm{AE}} \mathrm{H}^{-}\right]_{\mathrm{FF}}$ da-L\% $]_{\mathrm{IY}}$
B3: $\quad \#\left[\left[\mathrm{du} \quad\left[^{2} \mathrm{HADDe}-\mathrm{dem}\right]_{\mathrm{AE}} \quad \mathrm{H}^{-}\right]_{\mathrm{FF}} \quad\left[\left[^{1} \text { med-deg-da-du-gikk }\right]_{\mathrm{AE}}\right.\right.$ $\left.\left.\left[{ }^{2} \mathrm{HJEMMefra}\right]_{\mathrm{AE}} \mathrm{H}^{-}\right]_{\mathrm{FF}} \mathrm{a}-\mathrm{L} \%\right]_{\mathrm{IY}}$

(28) B1 er en inkoherent reaksjon på utsagnet til A. B ønsker å få bekreftet at $\mathrm{A}$ tok med seg solbriller ut, men $\mathrm{A}$ har allerede fortalt at det motsatte gjelder. Talehandlingen i (27)/(27') B2 var et adversativt spørsmål i den forstand at B presenterer sin egen oppfatning av det beskrevne saksforholdet som annerledes enn hva A synes å huske. (28) B2 er strukturelt identisk med (27) B2, men innholdet i ytringen til A viser at talehandlingen til B i (28) B2 må være en påstand, mer nøyaktig en avvisning av A's påstand. Både setningen og partikkelen representerer produsentens eget syn.

Jeg har slått fast at partikkelen $a$ er uforenlig med talehandlingstypen påstand. Den indikerer at $\mathrm{B}$ metarepresenterer en tanke som ikke er B's egen, men som reflekterer hvordan B tror at A tenker. Partikkelen forteller at $\mathrm{B}$ holder den negative motsatsen til den metarepresenterte proposisjonen for å være sann (inntil det motsatte er bevist), men denne negative proposisjonen er jo nettopp den som A påstår er sann. B synes dermed å motsi seg selv i (28) B3. Før det punktet hvor partikkelen blir lagt til utsagnssetningen, virker det som om $\mathrm{B}$ påstår at $\mathrm{A}$ tar feil. Dette fungerer greit i (28) B2 hvor partikkelen er $d a$. Der er det samsvar mellom semantikken i utsagnssetningen og den konteksten som $d a$ representerer. Begge deler gjenspeiler B's eget syn. Partikkelen $a$ i B3 forteller oss derimot at B ikke tror på den tanken som er uttrykt i utsagnssetningen, så ved B3 står vi overfor gjensidig motstridende oppfatninger om virkeligheten $i$ en og samme ytring. Partikkelen $a$ informerer på den ene siden om at B støtter det negative motstykket til den metarepresenterte positive proposisjonen, men på den andre siden indikerer den at produsenten er uenig med adressaten. $A$ gjør dermed B3 til en meningsløs reaksjon på utsagnet til A. 


\section{da og $a$ etter interrogativer}

Bruk av intonasjon som imiterer en tenkt bekreftelse fra adressaten, er like aktuell når vertskapssetningen til $d a$ eller $a$ er interrogativ, som når den er deklarativ. Intonasjonen i (29) fungerer som imitasjon av noe produsenten antar at adressaten kunne ha sagt, med tone-topper $\left(\mathrm{H}^{-}\right)$plassert akkurat som i Figur 2, bortsett fra at det finitte verbet er i front, ikke i 2. posisjon.

$$
\begin{aligned}
& {\left[[ [ ^ { 2 } \mathrm { HADD } - d u - d e m ] _ { \mathrm { AE } } \mathrm { H } ^ { - } ] _ { \mathrm { FF } } \left[[ { } ^ { 1 } \text { med-deg-da-du-gikk } ] _ { \mathrm { AE } } \left[{ }^{2} \mathrm{HJEMM}\right.\right.\right.} \\
& \text { efra } \left.\left.]_{\mathrm{AE}} \mathrm{H}^{-}\right]_{\mathrm{FF}} \text { da-L\% }\right]_{\mathrm{IY}}
\end{aligned}
$$

En ytring av (29) kan oppfattes som et nøytralt spørsmål om å få bekreftet at den uttrykte tanken er sann, men når intonasjonen som er lagt oppå en interrogativ setning, inneholder polaritetsfokus på det finitte verbet, går tankene lett i retning av en skeptisk holdning hos produsenten, selv når ytringen ikke inneholder noen etterstilt partikkel. Derfor er det heller ikke noen nevneverdig pragmatisk forskjell mellom (29) med $d a$ og (30) med $a$.

$$
\begin{aligned}
& {\left[\left[{ }^{2} \mathrm{HADDe}-d u-d e m\right]_{\mathrm{AE}}\right.} \\
& \text { efra } \left.\left.]_{\mathrm{AE}} \mathrm{H}^{-}\right]_{\mathrm{FF}} \mathrm{a}-\mathrm{L} \%\right]_{\mathrm{IY}}
\end{aligned}
$$

Likevel er det bare $a$ som koder en mistro til den uttrykte tanken og blokkerer alle andre tenkelige tolkninger.

\section{da og a etter imperativer}

Etter imperativsetninger kan man høre både $d a$ og $a$, men som $\mathrm{i}$ andre syntaktiske omgivelser er det strengere strukturelle restriksjoner på $a$ enn på da. La oss tenke oss at to kamerater A og B er oppe på fjellet Preikestolen $\mathrm{i}$ Rogaland. A har en redsel for å bevege seg nær stupet, uttaler seg som vist $\mathrm{i}$ (31), og får ytringen til $\mathrm{B}$ som reaksjon. B oppfordrer A til å handle i samsvar med hva som kjennes trygt for A.

$$
\begin{array}{ll}
\text { A: Jeg har virkelig ikke lyst til å gå ut på kanten. } \\
\text { B: } & {\left[\left[\text { ikke }\left[{ }^{1} \mathrm{G} \AA\right]_{\mathrm{AE}} \mathrm{H}^{-}\right]_{\mathrm{FF}}\left[{ }^{1} \text { ut-på }\right]_{\mathrm{AE}}\left[{ }^{1} \text { kanten }\right]_{\mathrm{AE}} \text { da-L\%/*a-L\% }\right]_{\mathrm{IY}}}
\end{array}
$$

B kan presentere det faktum at A ikke har lyst til å nærme seg stupet, som en gjensidig manifest tanke $\mathrm{i}$ og med opplysningen til A. Den negative imperativen i (31) B uttrykker en naturlig konsekvens av A's følelse av ubehag. Fokus i responsen til B er på den negative polariteten, her uttrykt ved hjelp av fokal aksentuering av imperativformen gå etter negasjonen. Resten er bakgrunnsinformasjon som ikke trenger å bli uthevet med fokal aksentuering. Sammenhengen mellom partikkelen $d a$ og betingelsesanaforen $d a$ («Da går du ikke ut på kanten») er klar her, så den konsonantløse partikkelen $a$ som betyr et totalt brudd med anaforen, kan ikke brukes $\mathrm{i}$ ytringen til B i (31). 
I (32) er intonasjonen en annen, så ytringen kontekstualiserer på en annen måte enn i (31). (32) er en advarsel og en oppfordring til adressaten om å fjerne seg fra kanten. Produsenten har lagt merke til at adressaten beveger seg farlig nær stupet, og syns det er uforsvarlig.

$$
\left.\left[\left[{ }^{2} \text { ikke }\right]_{\mathrm{AE}}\left[{ }^{1} \text { gå }\right]_{\mathrm{AE}}\left[{ }^{1} \text { ut-på }\right]_{\mathrm{AE}}\left[{ }^{1} \mathrm{KANten}\right]_{\mathrm{AE}} \mathrm{H}^{-}\right]_{\mathrm{FF}} \text { da-L\%/a-L\% }\right]_{\mathrm{IY}}
$$

Det gir ikke mening å si at produsenten metarepresenterer en tanke som tillegges adressaten $\mathrm{i}$ et tilfelle som dette, men det kommuniseres at det foreligger en konflikt mellom adressatens adferd før ytringsøyeblikket og produsentens tanker om den, og det er rimelig å tro at dette i det minste delvis forklarer hvorfor $a$ er et akseptabelt alternativ til $d a$ i (32). En minst like vesentlig rolle spiller nok det faktum at det ikke finnes noen forutgående kontekstskapende diskurs som partikkelen kan forbindes med. I (31) kan da derimot lett assosieres med innholdet i ytringen til A, og det setter bom for bruk av alternativet $a$ der, en partikkel som forutsetter et avvik fra den mentale konteksten til adressaten, slik produsenten har tolket den.

\section{Konklusjon}

Modalpartikkelen $d a$ er resultatet av grammatikalisering av det anaforiske adverbet $d a$, en diakron prosess som innebærer tap av den sannhetsbetingelsen som dette indeksikalske ordet får når det forbindes med en diskursantesedent i den pragmatiske delen av arbeidet med å forstå hva som kommuniseres. $A$ som partikkel på slutten av en norsk ytring skyldes ytterligere en grammatikaliseringsprosess, grammatikalisering av partikkelen $d a$. $A$ kan ikke brukes på noen måte som det ikke finnes dekning for innenfor brukspotensialet til $d a$, men denne monosegmentale partikkelen innsnevrer det brukspotensialet som gjelder for $d a$, og dermed gjør den det presumptivt lettere for adressaten å aktivere mentalt den konflikten, oftest av epistemisk art, mellom produsent og adressat som den prosedurale semantikken til partikkelen $a$ legger opp til når vertskapssetningen er en utsagnssetning, en polær spørresetning eller en imperativsetning.

Jeg har vist at den sekundære grammatikaliseringen av partikkelen $d a$ som førte til utvikling av partikkelen $a$, er begrenset til én bruk av $d a$. $D a$ modifiserte ytringer i påstander eller ledende spørsmål om bekreftelse ble ikke berørt. $D a$ kan erstattes av $a$ bare når produsenten tillegger adressaten troen på at den uttrykte proposisjonen er sann, men selv stiller seg tvilende til den. At nettopp denne bruksmåten ble utsatt for grammatikalisering med partikkelen $a$ som resultat, støtter tanken om en leksikalsk polysemi-relasjon mellom den adversative bruken av $d a$ og de øvrige bruksmåtene hos den delen av den norske befolkningen som praktiserer veksling mellom $d a$ og $a$. Den bruksmåten som skiller seg klarest ut fra de øvrige i sin funksjon, vil naturlig nok være mest utsatt for en endring i partikkelens fonologiske 
utseende, og den formelle endringen har åpnet for utvikling av en ny modalpartikkel i det norske talespråksleksikon.

\section{Litteraturliste}

Allott, Nicholas (2017), "Metarepresentation", i Anne Barron, Yuego Gu \& Gerard Steen (red), The Routledge Handbook of Pragmatics. London: Routledge, 295-309.

Ahern, Aoife \& Leonetti, Manuel (2004), "The Spanish subjunctive: Procedural semantics and pragmatic inference", i Rosina Márquez-Reiter \& María Elena Placencia (red), Current Trends in the Pragmatics of Spanish. Amsterdam: John Benjamins, 35-56.

Berthelin, Signe Rix (2018), "Midtstilt $d a$ - en semantisk-pragmatisk redegjørelse og en sammenlikning med etterstilt da, Norsk Lingvistisk Tidsskrift 36(2), 353-402.

Blakemore, Diane (1987), Semantic Constraints on Relevance. Oxford: Blackwell Publishing.

Blakemore, Diane (2002), Relevance and Linguistic Meaning: The Semantics and Pragmatics of Discourse Markers. Cambridge: Cambridge University Press.

Borthen, Kaja (2014), “Hva betyr 'da', da?”, Norsk Lingvistisk Tidsskrift 32(2), 257-306.

Breban, Tine (2014), "What is secondary grammaticalization? Trying to see the wood for the trees in a confusion of interpretations", Folia Linguistica 48(2), 469-502.

Carston, Robyn (1988), "Implicature, explicature, and truth-theoretic semantics", i Ruth Kempson (red), Mental Representations: The Interface Between Language and Reality. Cambridge: Cambridge University Press, 155-181.

Carston, Robyn (2002), Thoughts and Utterances: The Pragmatics of Explicit Communication. Oxford: Blackwell Publishing.

Clark, Herbert H. \& Catherine R. Marshall (1981), "Definite reference and mutual knowledge", i Aravind Joshi, Bonnie Lynn Webber \& Ivan Sag (red), Elements of discourse understanding. Cambridge: Cambridge University Press, 10-63.

Escandell-Vidal, Victoria, Manuel Leonetti \& Aoife Ahern (2011) (red), Procedural Meaning: Problems and Perspectives. Bingley UK: Emerald Group.

Fretheim, Thorstein (1987), "Pragmatics and intonation", i Jef Verschueren \& Marcella Bertucelli-Papi (red), The Pragmatic Perspective. Amsterdam: John Benjamins, 395-420.

Fretheim, Thorstein (1989), "The two faces of the Norwegian inference particle $d a$ ", i Harald Weydt (red), Sprechen mit Partikeln. Berlin: Walter de Gruyter, 403-415.

Fretheim, Thorstein (1991), "Intonational phrases and syntactic focus domains", i Jef Verschueren (red), Levels of Linguistic Adaptation. Amsterdam: John Benjamins, 81-112. 
Fretheim, Thorstein (1992a), "The effect of intonation on a type of scalar implicature", Journal of Pragmatics 18(1), 1-30.

Fretheim, Thorstein (1992b), "Themehood, rhemehood and Norwegian focus structure", Folia Linguistica 28, 111-150.

Fretheim, Thorstein (2000), "Procedural encoding of propositional attitude in Norwegian conditional clauses", i Gisle Andersen \& Thorstein Fretheim (red), Pragmatic Markers and Propositional Attitude. Amsterdam: John Benjamins, 53-84.

Fretheim, Thorstein (2002), "Intonation as a constraint on inferential processing”, i Bernard Bel \& Isabelle Marlien (red), Speech Prosody 2002. Aix-en-Provence: SProSIG, Université de Provence, 59-64.

Fretheim, Thorstein (2010), "The metarepresentational use of main clause phenomena in embedded clauses", Linguistics 48, 301-324.

Fretheim, Thorstein (2011), "Description as indication: the use of conceptual meaning for a procedural purpose", i Escandell-Vidal \& al, 131-156.

Fretheim, Thorstein (2014), "Et relevansteoretisk blikk på likheter og forskjeller mellom partiklene da og altså”, Norsk Lingvistisk Tidsskrift 32(2), 197256.

Fretheim, Thorstein (2015a), "A relevance-theoretic perspective on the Norwegian utterance-final particles $d a$ and altså compared to their English counterpart then", i Sylvie Hancil, Alexander Haselow \& Margje Post (red), Final Particles. Berlin: de Gruyter Mouton, 249-284.

Fretheim, Thorstein (2015b), "Grammatikalisering av adverbet gjerne i ulike varieteter", Norsk Lingvistisk Tidsskrift 33(1), 3-48.

Fretheim, Thorstein (2017a), "The pragmatics of Yes and No", i Stavros Assimakopoulos (red), Pragmatics at Its Interfaces. Berlin: de Gruyter, 175-200.

Fretheim, Thorstein (2017b), "Instead", i Agnieszka Piskorska \& Ewa Wałaszewska (red), Applications of Relevance Theory: From Discourse to Morphemes. Newcastle upon Tyne: Cambridge Scholars Publishing, 64-85.

Fretheim, Thorstein (2017c), "The form and function of extrametrical, unaccented segments of East Norwegian utterances", i Jardar Eggesbø Abrahamsen, Jacques Koreman \& Wim A. van Dommelen (red), Nordic Prosody: Proceedings of the XII ${ }^{\text {th }}$ Conference. Frankfurt am Main: Peter Lang, 9-28.

Fretheim, Thorstein (2018), "Vel i spørresetninger: en pragmatisk analyse", Norsk Lingvistisk Tidsskrift 36(1), 5-40.

Fretheim, Thorstein (2019), "The polysemy of a Norwegian modal adverb", i Kate Scott, Billy Clark \& Robyn Carston (red), Relevance, Pragmatics and Interpretation. Cambridge: Cambridge University Press, 163-173.

Fretheim, Thorstein, Stella Boateng \& Ildikó Vaskó (2002), “Then - adverbial pro-form or inference particle? A comparative study of English, Ewe, Hungarian, and Norwegian", i K.M. Jasczcolt \& Ken Turner (red), Meaning Through Language Contrast Vol 2. Amsterdam: John Benjamins, 51-74. 
Fretheim, Thorstein \& Randi Alice Nilsen (1992), "The Norwegian broad-focus avoidance strategy", i Björn Granström \& Lennart Nord (red), Nordic Prosody VI. Stockholm: Almqvist \& Wiksell, 49-64.

Fretheim, Thorstein \& Wim A. van Dommelen (2012), "A pragmatic perspective on the phonological values of utterance-final boundary tones in East Norwegian intonation", The Linguistic Review 29(4), 663-677.

Givón, T. (1991), "Markedness in grammar: Distributional, communicative and cognitive correlates of syntactic structure", Studies in Language 15(2), $1-42$.

Grice, H. Paul (1989), Studies in the Way of Words. Cambridge, MA: Harvard University Press.

Hall, Alison (2007), "Do discourse connectives encode concepts or procedures?", Lingua 117: $14-174$.

Nilsen, Randi Alice (1992), Intonasjon i interaksjon. Sentrale spørsmål i norsk intonologi. Dr.art.-avhandling, Universitetet i Trondheim.

Noh, Eun-Ju (2000), Metarepresentation. Amsterdam: John Benjamins.

Sperber, Dan (2000), Metarepresentations: A Multidiscliplinary Perspective. Oxford: Oxford University Press.

Sperber, Dan \& Deirdre Wilson (1986/1995), Relevance: Communication and Cognition. Oxford: Blackwell Publishing. (utvidet 1995-utgave)

van Dommelen, Wim A., Thorstein Fretheim \& Randi Alice Nilsen (1998), "The perception of boundary tone in East Norwegian", i Stefan Werner (red), Nordic Prosody: Proceedings of the VII th Conference, Joensuu 1996. Frankfurt am Main: Peter Lang, 76-86.

Wilson, Deirdre (2011), "The conceptual-procedural distinction: Past, present and future", i Escandell-Vidal \& al, 3-32.

Wilson, Deirdre (2016), "Reassessing the conceptual - procedural distinction", Lingua 175/176, 5-19.

Wilson, Deirdre \& Dan Sperber (1993), "Linguistic form and relevance", Lingua 90, 1-25. 